\title{
correspondence
}

\section{Sinking of 'Cavtat'}

SIR,-With regard to the report by Alastair Hay (26 May, page 301), on the sinking of the Yugoslav ship 'Cavtat', off the coast of Otranto in southern Italy, I understand that there is no evidence that poisonous lead derivatives have leaked from the drums in which they are sealed.

The article, however, is decorated with the picture of an Italian fisherman holding fish, with the caption "Poisoned fish caught in the Gulf of Taranto". That picture and caption will certainly capture the attention of most readers of Nature, and it will mislead them into thinking that if they visit that area, they will be at high risk of being poisoned. Because this is clearly not the case, the above picture seems ungenerous toward the people of the area, who are heavily dependent on tourism and may suffer from the effect of an unfortunate picture and caption published in an authoritative journal like Nature.

Francesco Bresclani

Department of Pathology,

University of Toronto, Canada

\section{Effects of marine research}

SIR,-Each time I re-read Desmond Scott's assessment (30 June, page 762) of the effects on marine research of the Third United Nations Conference on the Law of the Sea, I get more annoyed. It is not that his forecast seems improbable-coastal states are indeed likely to exert total control over all scientific research on their continental shelves and within 200 miles of their shores. But the account of how this situation arose and how it should be cured exhibits a curious bias.

Scott appears to attribute all political difficulties between developing and developed countries, especially as they pertain to ocean resources and jurisdiction, to the marine scientists. His view of them is surprisingly bitter and unfortunately misleading. I contend that the scientists had little to do with creating the problem and can do little to solve it. In the confrontation between the developed and developing countries, related as it is to the history of colonialism and its children, postand neo-colonialism, and accompanied by the emergence of the 'new economic' order', marine science has played a pretty trivial role.

The issue of control over marine science was initially evoked for bargaining purposes, could well have been dropped once the question of jurisdiction over coastal resources was settled, and now refuses to go away, to the great eventual cost of all who use the ocean and its resources or are affected thereby. International interactions under the new law of the sea will be among governments, not individuals, and there are few governments whose actions are determined by scientists, especially when larger political forces are at play.

WARREN S. WOOSTER

Institute of Marine Studies, University of Washington, USA

\section{Harvesting whales}

SIR,-In your 'in brief' columns (16 June, page 576) there is a confused and inaccurate account of some analyses I have done on the dynamics of harvested populations. Particularly misleading is a belief attributed to me that certain whale species are under the threat of extinction due to the dynamic instability of the harvesting strategy. I have never made any statement to this effect and do not believe it to be true. Indeed the idea is absurd.

$$
\text { JOHN BEDDINGTON }
$$

Department of Biology,

University of York, UK

\section{Darwin and his flowers}

SiR,--In view of your reviewer's acceptance of "the role of plants in Darwin's scientific life," (21 July, page 273) it may be of interest to mention that in a collection of unpublished letters from eminent botanists and gardeners, written to the late William Robinson, editor of The Garden (1871-1927), and preserved by a member of this Association related to Robinson, are some written by Charles Darwin from Downe, Kent in 1875.

On 4 January he wrote: " $x$ am much obliged for your kind gift of six copies of The Garden, with a drawing of myself and a notice of my works. This notice is drawn up in the most generous spirit and is highly honourable to me. I thank the writer very sincerely."

In a further letter he wrote: "I may mention (though it is improbable) that you can aid me on one point. If you have some Euralye ferox, and if it produces more than one flower at a time, I wish you would cross some and fertilise some others with their own pollen, in order to see, when their seeds are counted, whether the cross aids at all in increasing their fertility. The Euryale is dead at Kew where they would have made the trial on a large scale for me. Professor Carpavy (?) has advanced this plant as a case of self-fertilisation for many generations with unimpaired fertility."

$\mathrm{He}$ also asked for some experiments with two distinct plants of Nymphaea which were protected while expanded from insects. On 5 May he wrote: "I write ... to thank you and to say that it will be superfluous to castrate the flowers which are crossed with a pollen from a distinct plant, grown under as different circumstances . . . as maybe. ... The flowers fertilised with their actually own pollen should certainly be protected from insects. . . . I was glad to see you elected to the Linnaean Society."

Charles Darwin's chief contribution seems to have been to make the world realise that plants have a history as well as a structure which had been the sole concern of most botanists. ERIC HaRdY

Merseyside Naturalists' Association, Liverpool, UK

\section{Grants for social science}

SIR,-The article 'Research on research' (4 August, page 398) refers to the sum of $£ 25,000$ transferred to the Social Science Research Council (SSRC) from the Council of Scientific Policy (CSP) for science policy studies. You state that the research grant to the Science Policy Research Unit (SPRU) at the University of Sussex "means that other applications are denied". This is untrue, and is a misunderstanding of SSRC's procedures.

The grant made to SPRU is under the SSRC's research grant scheme, and the funds come from the general research grant allocation. The sum transferred to SSRC from CSP for science policy studies is at the disposal of the Research Initiatives Board (RIB) for research contracts. Should the RIB and Council decide to give greater priority to science policy studies it is up to them to take a further initiative in this area.

It is therefore untrue that the research grant to SPRU closes the door to other applicants.

DAVID WAINWRIGHT

Social Science Research Council,

London, UK 